\title{
Securitization as Hegemony
}

\section{Hannah Broecker and Carola Westermeier}

\section{Introduction}

How can we trace power in the study of security and securitization? Particularly, how can we analyze the power of securitization and the power to securitize? In a broader sense, how can we analyze how differing political projects struggle for power in political processes? We propose that the study of securitization would benefit greatly from integrating insights of hegemonic discourse theory to include more explicitly the study of the constitution of power. Further, hegemony theory is able to encompass dynamics which go beyond the classical scope of securitization. In this manner, hegemony theory enables us to analyze the aspects of power in discourse which lead to (de-)securitization as well as the effects of a momentary discursive formation of securitization which is usually the end-point of such studies. In our empirical study of the securitization of 'financial stability,' we can observe that while political actors undertook securitizing moves and did employ extraordinary means in response to it, they were unable to control the effects of securitization.

Securitization as a concept has greatly enhanced our understanding of the social construction of issues as relevant to security. The latest wave of conceptual work on securitization along the lines of the Copenhagen School (CS) has increasingly argued for the need of securitization to be understood within a discourse theoretical framework and has engaged with the implications which the CS approach produces within such a setting. ${ }^{1}$ However, few works have engaged with the implications of hegemony discourse analysis for that framework. This is surprising, since the CS concept is based on strong assumptions of social and political power-centres, and its proponents have regularly had to engage with criticism thereof. In this contribution, we propose to combine the Copenhagen concept of securitization with hegemonic discourse theory as developed by Ernesto

1 See Stritzel 2007. 
Laclau and Chantal Mouffe. This, we hope, will be a starting point for reevaluating a number of theoretical inconsistencies within the CS approach, and for offering tools for a clearer analysis a) of the discursive dynamics through and in which securitization manifests, b) of the likelihood for attempted securitizations to be successful or not, and c) regarding what happens after the moment of securitization. We will illustrate the theoretical link of the two approaches and its advantages through a case study on the securitization of 'financial stability' during and after the financial crisis of 2008.

The concept of securitization has its origins at the threshold between the domestic sphere and International Relations (IR). It was originally conceptualized in the context of the immediate post-Cold War era and introduced aspects of the constructivist and linguistic turn of social sciences into the discipline of International Relations. It has been a fundamental contribution to the discipline of IR by adding a layer of considerations based on constructivism and intersubjectivity to the understanding of dynamics of security, which had previously been dominated by the realist tradition of International Relations and its approach of largely blackboxing domestic affairs. While this heritage of combining the theoretical approaches of realism and constructivism renders securitization an innovative and enticing analytical concept, it simultaneously introduces theoretical challenges which so far remain unresolved.

This holds particularly for the 1998 approach ('Security: A New Framework for Analysis') but also for many of those works criticizing and amending the resulting challenges. These challenges find their origin in the fact that the Copenhagen approach to securitization adapts concepts and theoretical insights from sociological, linguistic and constructivist schools but is not always able to do so coherently while maintaining one foot in the door of a positivist ontology of the realist International Relations (IR) perspective. While the speech act approach of the CS is helpful by directing our attention to the performativity of security, it is ultimately unable to explain the overall success or failure of instances of constructing securitization. To be able to do so, the approach would have to explain the socio-political and ultimately discursive dynamics that lead to the (in)effectiveness of speech acts. The CS approach, in pre-supposing on the one hand the self-referential grammar of security and on the other hand focusing on a pre-determined end-point of securitization, remains largely descriptive. Lastly, the approach also lacks clarity on whether power both of securitization, i.e. the effects induced through securitization, and the pow- 
er to securitize, i.e. the influence to create a momentum of securitization, are likely to be found in aspects of agency or structure ${ }^{2}$. In this manner, it has been argued, that securitization is an agency-centred concept as it depends on the authoring of individual, intentional speech acts by actors. ${ }^{3}$ At the same time, the heavy reliance on pre-existing positions of power and influence such as those embodied in the speaker's position and the assumption of predictable interests by the political elites relate back to aspects of context and structure as the central variable.

In order to be able to gain in explanatory potential, insights generated by the CS need to be integrated within the framework of a discourse-based approach. Such an approach would benefit from a more coherent inclusion of insights from societal constructivism. Specifically, it needs to bring together a consistently constructivist understanding of power and the dynamics constituting it. Further, such an approach needs to explicate the place and limits of speech act theory within a larger theory of discourse. The lack of such a coherent theoretical integration causes the approach to stay rather close to state-centrism and to affirm the very conceptions of interest and power of the traditional approaches of IR, which it criticizes and seeks to reform. The latter of these points is particularly clear in the explicitly normative imperative for de-securitization. It is the key argument of this article that securitization along the lines of the CS can and should be understood and conceptualized as a specific form of hegemonic project, and that such a theoretical tightening can produce deeper insights into the dynamics of securitization.

This article focuses on the integration of those insights generated by the line of understanding of the Copenhagen School but also to some degree those of the Paris School. We propose to use Ernesto Laclau's and Chantal Mouffe's post-structural discourse theory to approach the notion of hegemony.

In their work, Laclau and Mouffe argue that power struggles must not be analysed or reduced according to given or natural(ized) social entities, such as class. They seek to show how these entities are constituted and socially constructed in the first place and come to be represented by "empty signifier(s)". ${ }^{4}$ The empirical case study in this article analyzes the development of 'financial stability' as the empty signifier of a securitized hege-

2 See Langenohl's contribution to this volume, pp. 25-66.

3 See Stritzel 2012, p. 552.

4 Laclau/Mouffe 1985, p. 128. 
monic construction. Treading in the footsteps of Gramsci, hegemony has been described as a multi-faceted category which entails two aspects: 'First, hegemony is a type of political practice that captures the making and breaking of political coalitions. Secondly, hegemony can be seen as a form of rule that can elucidate the way in which a regime, practice or policy holds sway over a set of subjects by winning their consent or securing their compliance'. ${ }^{5}$ These two aspects of hegemony by nature involve the exclusion of such positions and persons not subsumed under the collective hegemonic position and thereby the exercise of power. Through this, both aspects of hegemony help to unravel the broader notion of power, especially the power to securitize and the power of securitization as logics connected to the constitution of polities and entailing claims to representing society. Hegemonic analysis can add to our understanding as to how securitization occurs and why it is 'successful' in some cases but not others. In this, it harbours the potential to go beyond the classical Copenhagen approach, adding explanatory power regarding the success of securitization attempts through re-constructing the constitution of hegemonic discourse formations and simultaneously widening the array of dynamics that can be analyzed within its scope. It could encompass, for example, a re-thinking of the role which contestation plays in allowing for the success of securitization (see also Bloom and Dallyn, 2011). It can also encompass a rethinking of the role securitization itself plays in maintaining the stability of that which it claims to be threatening In the case of 'financial stability,' this could relate to the question: how does the securitization of 'financial stability' lead to a (de-)stabilization of the financial system within which such a crisis could occur in the first place?

In our example, the prevailing pre-crisis discourse could no longer handle the issues that arose with the events of the crisis. It was not able to integrate different articulations stated by differing subject-positions. Subsequently, a discursive formation evolved which temporarily brought together differing demands and thereby made a hegemonic claim. It will be shown that 'financial stability' was used as a referent object of securitization in the Copenhagen sense. In the following phase of financial policymaking, it provided an anchor for the discourse on financial regulation that brought together multiple articulations. However, as differences between articulations gain importance, it becomes obvious that the initial

5 Howarth 2010. See also Cox 1996, p. 151. 
referent object has to be understood as an 'empty signifier' that remains an abstract code to which multiple articulations can relate. The empirical analysis - an illustration of discourse, based on statements and reports by relevant actors within the field of financial regulation - serves as an illustration of the utility of the theoretical approach proposed here.

The first part of the article is dedicated to the theoretical outline of our proposal. We start out by giving a condensed insight into the central tenets of the theory of hegemony by Laclau and Mouffe and continue to outline the manner in which securitization approaches and discourse analysis of hegemony can be fruitfully combined. It is noteworthy that we focus on their earlier post-Marxist understanding of hegemony ${ }^{6}$ and not on the later, psychoanalytically inspired work. What follows in the second part of the article is an empirical analysis of the discourse on financial regulation according to the proposed model.

\section{Hegemony according to Laclau and Mouffe}

Based on the insights of linguistic post-structuralism, Laclau and Mouffe hold that any understanding is produced through the signification of differences and interrelations between individual signifiers or subject-positions in a discourse. No subject matter, symbolic or material, can be represented as itself but only in relation to other subject matters. Differences and meaning thusly constituted further rely on the understanding that any sign consists of a signifier and a signified.

Hegemony in this conceptualisation essentially refers to the nature of the relationship between different social subject-positions in discourse. As mentioned previously, the perspective holds that categories according to which individual issues are analyzed - such as class, gender, and also security - are not given. ${ }^{7}$ Laclau and Mouffe argue that the emergence of such entities can best be understood by an analysis of discourse, more specifically, the moment of formation of social and political constellations. They find that a hegemonic construction is essentially a particular discursive formation that brings together several individual positions such as demands, views, hopes, fears and other forms of articulation under one po- 
litical umbrella. ${ }^{8}$ The concept of articulation here refers to "any practice establishing a relation among elements such that their identity is modified as a result of the articulatory practice. The structured totality resulting from the articulatory practice, we will call discourse". 9 At its core, hegemony thus allows for different subject-positions - to relate to one or a group of hegemonic concepts - such as class or, in our case, a specific claim to (in)security. Hegemonic formations hence occur when different subject-positions coalesce around one or several signifiers, which are constructed to represent these various positions. Laclau and Mouffe term this the chain of equivalence. 10 "They [signifiers] are the points of identification that unite otherwise disparate groups, for instance the flag in a nationalist discourse". ${ }^{11}$ Through creating what may be called an anchor to the discursive formation, hegemonies organize the elements they subsume and make them intelligible in a particular way. While the individual positions included in a hegemonic construction hence differ and may even contradict each other in some respects, such differences are subordinated to that which is constructed to unite them and which is expressed through the empty signifier(s). The empty signifier(s) are hence constructed to stand in for the entire system of differences, which represents the discourse rather than any particular position within it. ${ }^{12}$ In our case study, the signifier 'financial stability' unites a range of differing positions, such as demands articulated by politicians, as well as those of bankers and regulators, without representing a particular subject position.

The logic of differentiation between a hegemonic discourse and that which is outside of it, is of a different nature than those differences between individual positions within a discourse. Within a discourse, differences are necessary for the creation of meaning. The second logic of differentiation is that between a hegemonic construction and its outside. The outside of a hegemonic construction, which is always constituted by other discourses, necessarily represents that which has not yet or cannot be subsumed under the hegemonic chain of equivalences. It demarcates that which curtails the potential for completeness of the hegemonic construc-

8 Id., pp. 128, 152.

9 Laclau/Mouffe 2001, p. 105.

10 Laclau/Mouffe 1985, p. 130.

11 Thomassen 2016, p. 166.

12 See, for example, Laclau/Mouffe 1985, p. 148. 
tion and, in this manner, threatens its existence - the antagonist divide. ${ }^{13}$ Instead of the individual differences, these subject-positions enter into an antagonist relationship with that which is beyond the boundary of this chain of equivalence. Simultaneously, it is this antagonist outside which creates the conditions of possibility for the construction of a chain of equivalence, the subjugation of differences between positions within the discourse and, hence, the construction of hegemony in the first place. ${ }^{14}$ Laclau and Mouffe hold that a hegemonic discourse formation is only possible when, in addition to the presence of antagonist forces, the possibility is given that elements can be articulated to the constitutively opposite camps of an antagonist formation. While they utilize the term 'moments' to signify those entities which have been articulated as part of a discourse, they refer to 'elements' as those signifiers "incapable of being wholly articulated into a discursive chain". ${ }^{15}$ Because of the vast field of signifiers which is not fully articulated, we must distinguish between discourses (with fixed articulations, i.e. 'moments') and the field of discursivity in which unarticulated 'elements' occur and which presents us with a surplus of meaning. The field of discursivity is hence also always a field of undecidability in which a surplus of meaning exists which cannot be wholly subsumed into any discursive formation and which therefore constantly undermines this system of articulation. ${ }^{16}$ Hegemony then presents a momentary decision of articulation which is nevertheless placed within a wider field of undecidability. That is to say, elements might also be articulated as part of the chain of equivalence constructed to oppose the hegemonic one. ${ }^{17}$ This also implies that while hegemonic discourse formations organize discourses and claim to represent decidability (through implying order and logic), the overall terrain of discursivity remains one of undecidability, and the hegemonic discourse formation remains unstable. In our case study, this aspect becomes obvious in the fact that the meanings subsumed under 'financial stability' are constantly evolving, and finally the empty signifier becomes unable to subsume their differences.

Inherent in this understanding of hegemony and antagonism - which are always political projects - is the strive to overcome that which is seen

13 Id., pp. 111, 130.

14 See, for example, Howarth 2015, pp. 67, 68.

15 Laclau/Mouffe 1985, p. 99, see also p. 97.

16 Id., pp. 97, 100.

17 Id., p. 122. 
to restrict the vision of a hegemonic totality. ${ }^{18}$ This attempt is, however, necessarily bound to fail as the hegemonic construct, represented in the chain of equivalence and the empty signifier, depends on the antagonistic struggle for its own definition and thereby existence. ${ }^{19}$ To give an example, the identity of the discourse in question might be the representation of 'The Free World.' ${ }^{20}$ This identity, which represents multiple subject-positions identified with different and potentially opposing discursive objects, relies on a definition of that which curtails the totality of that 'Free World' - thereby positioned on the other side of the antagonistic line. This could be terrorism, underdevelopment, militant Islam or, in fact, almost any other object constructed in radical difference (i.e. constitutional opposition) to the term 'Free World.' The desire for a complete identity thus includes the striving to eradicate those factors which are seen to curtail it. Were it possible to eradicate these factors, however, this would not lead to the completion of the hegemonic construct as 'The Free World' but to an impossibility to uphold this identity for lack of an antagonist Other against which it could be defined. This is what Laclau and Mouffe refer to as antagonism constituting both the possibility and impossibility of identity. ${ }^{21}$

The understanding, following from the above, that "a discursive structure is not a merely 'cognitive' or 'contemplative' entity; it is an articulatory practice which constitutes and organizes social relations" is vital here. ${ }^{22}$ It means that hegemonic constructions imply both power and the social creation of knowledge through establishing a logic according to which the elements of a discourse are understood and made sense of. Hegemonic analysis offers us the analytical tools to add such a conceptualisation on the level of the power of securitization and the power to securitize.

18 See also Nonhoff 2006, pp. 94, 105.

19 Laclau/Mouffe 1985, p. 148.

20 The term 'identity' is, in this text, used to refer to the hegemonic construct which defines an entire discourse and binds together various subject-positions.

21 Laclau/Mouffe 1985, p. 120; Howarth 2015, p. 68.

22 Laclau/Mouffe 1985, p. 82. 


\section{The signifier 'security'}

A theoretical focus on the dynamics of signification is not uncommon to Critical Security Studies. Approaching 'security' as a thick signifier, Huysmans articulates such an understanding of security as a logic according to which "our relation to nature, other human beings and the self" becomes articulated and organized. ${ }^{23} \mathrm{He}$ argues accordingly that the security studies agenda needs to be concerned above all with the question of the

"meaning of security, that is, the signifying and thus ordering work of security practices. How does security order social relations? What does a security problematic imply? What does the signifier do to the discussion of the free movement of persons in the EU, for example? Rather than being a tool of clarification serving an agenda, the exploration of the meaning of security is the security studies agenda itself". ${ }^{24}$

From the analysis of IR literature, Huysmans identifies security as the logic of an abstract fear of death in modernity. The fear relates to a) abstract death itself, and b) the uncertainty, the lack of knowledge of where and when such death is to be expected. Security practices then become those practices and institutions through which this abstract fear becomes attached to concrete objects, and thus becomes manageable. ${ }^{25}$ We agree with much of this analysis. However, we propose to approach security through the avenue of the 'empty,' rather than 'thick' signifier for the following reasons. Firstly, security automatically results in an antagonistic relationship with that which is constructed to represent the lack of security - that is, insecurity. Secondly, and in line with Huysmans' analysis, we understand security as operating not on the level of the individual but on the level of the collective. Claims to security then assume to speak on behalf of the collectivity, of a vision of society. More concretely than the notion of 'abstract death,' however, security relates to the destruction or destabilization of intelligibility. It is this intelligibility which is theorized in great depth in Laclau and Mouffe's concept of discursive hegemony and the empty signifier. Thirdly, the empty signifier is strongly connected to the analysis of the constitution of identities and power-relations flowing into and from such claims of representing 'society.' Referencing hegemony theory can improve our understanding of the nature of the notion of 'ab-

23 Huysmans 1998, pp. 228, 231.

24 Id., p. 233.

25 Id., p. 235. 
stract death' as the demise of discursive intelligibility and aid in the analysis of which articulatory practices threaten the stability of the discursive system which provides such intelligibility. The power of securitization should then be conceptualized as the effect of securitization as a hegemonic discourse formation. The power of such a hegemonic discourse formation is to consolidate particular claims to representing 'society' and the order of intelligibility. Concretely, this power implies the structuring of the inclusion and exclusion of subject-positions and (types of) knowledge which are considered crucial in political struggles.

\section{'Lack' in securitization and hegemonic analysis}

Lack, in various forms and terminologies, plays a vital role in both the strand of hegemonic analysis proposed here and in the conceptualization of securitization along the CS. As outlined above, lack is that which curtails a perfect hegemonic formation. The empty signifier, binding together the chain of equivalence can, depending on the perspective, be either that which constitutes the claim to 'society' or the wished-for state of affairs (i.e. security), or that which threatens it. ${ }^{26}$ To give an example, whether, in the Cold War context, we conjure up the empty signifier which stands in for the dimension of threat and insecurity, i.e. 'communism,' or whether, on the contrary, we utilize the signifier representing security and the wished-for state of affairs, i.e. 'the West,' or 'economy of the free market,' we always refer to the antagonist divide which constitutes both of its sides. Security is then always the object which is constituted by lack. In either case, a negative ontology exists - that is, in either case a version of an ideal identity is counter-posed by that which threatens it. In either case, an antagonist line is drawn between that which is aspired and that which is perceived to threaten it. In an understanding of securitization as hegemonic discourse formation, we must hence negate the possibility of security being constructed outside of this logic of negativity, i.e. as pure positivity.

This relationship between lack and an aspired state of affairs essentially articulates processes that are similarly thought of in securitization approaches. They are directly described in CS-inspired approaches and indirectly referenced through the praxeological analyses of the Paris School 
(PS). In this manner, lack, communicated as antagonism in discourse or communicated through security practices, necessarily has to be present in order to formulate the endangerment of central components of the polity. In order for there to be a lack of security, there has to be something that threatens or restricts security - even if this something finds expression only through absence - such as the perceived absence of practices or institutions deemed proper to establish the imagined state of things. The articulation that a given referent object is threatened presupposes a perspective focusing on lack. ${ }^{27}$ In this manner, both the CS and hegemony discourse analyses describe a perceived lack.

While not all hegemonic formations are necessarily of a nature perceived as security-relevant, instances of securitization are necessarily attached to such mechanisms due to the combination of two factors: Firstly, the creation of an issue as security-relevant essentially pre-supposes the potential for destruction (i.e. abstract death). The drawing of an antagonistic line, dividing the referent object from that which is (understood to be) threatening its own logic of existence, is a direct consequence of this. Secondly, when we refer to securitization, we refer to a political practice. In this manner, issues of individual safety only become issues of security when framed as relevant aspects of the polity. As Martin Nonhoff argues, this refers to all political discourses that direct themselves at that which represents the societal whole, unity or the polity necessarily attempt to gain the largest possible representative power. In order to do so, they must attempt to incorporate a range of different positionalities under a common umbrella, thus aiming to achieve a hegemonic formation. ${ }^{28}$ It is the shared signification that emerges as the sum of various positionalities concerning one referent object. The referent object essentially runs parallel to the concept of the empty signifier, standing in for the chain of equivalence in our study of hegemonic formations. In this manner, and referring to our example below, 'financial stability' is both the referent object under threat and the signifier of a hegemonic discourse formation.

27 The analysis of 'lack' is central in Lacan's psycho-analytical work on identity and has been appropriated in Laclau's later work for the further study of (collective) identity in hegemonic discourse formations. However, we do not want to focus in this contribution on the wider study of aspects of identity. The term 'lack' is here utilised merely to signify that which curtails the totality of the chain of equivalence.

28 Nonhoff 2006, pp. 105, 106. 
However, this example, to be concretised in the second part of the article, also demonstrates that hegemony adds the perspective of the representation of various subject-positions. In our case, individual narratives of threat may focus on various referent objects such as shareholder interests, the security of savings, or democracy. These, however, may be able to coalesce around a theme that appears to represent all of these - namely 'financial stability'. In effect, what hegemonic theory can add here is an understanding that what is generically termed the 'referent object' may in fact be a fragmented coalition of various referent objects. As outlined in Neo-Gramscian approaches, the basic effect of this hegemonic phenomenon is a gain in power over the overall construction by becoming a source for the organization of meaning, thus creating and also disciplining 'knowledge' in relation to the individual positions it contains. ${ }^{29}$ The resulting understanding that a referent object may really be a collection of various and potentially conflicting views on referent objects and/or perspectives on how to approach these becomes relevant when considering the consequences of (attempted) securitizations. While securitization as a hegemonic formation on the one hand lends power to the positionalities it includes and shapes, on the other hand it renders the referent object a fuzzier concept, devoid of any particular meaning. Laclau and Mouffe outline this process in the example of individual demands voiced in the "repressive context of the Tsarist state." Here, they argue that "no movement for partial demands could remain confined within itself: it was inevitably transformed into an example and symbol of resistance." With individual struggles becoming subsumed under the empty signifier of 'opposition' or 'resistance' (to the political system), they simultaneously lose some of their specificity in representation. ${ }^{30}$

As a result, it is likely that a hegemonic formation loses its 'binding force' when the implementation of concrete measures demands specificity. As the unifying force of a hegemonic formation depends on the suppression of differences, the more concrete demands become, the less likely the unifying hegemonic formation is able to unite them with other specific demands. These dynamics lead to the dissolution of the hegemonic forma-

29 Herschinger 2014, p. 78.

30 Laclau/Mouffe 1985, p. 2, see also p. 4. An in-depth analysis of this matter can be found in Laclau and Mouffe's discussion on the seemingly contradictory logics of hegemony and autonomy (see, for example, id., pp. 126-131). 
tion, as we will also see in the case of the empty signifier 'financial stability.'

\section{The power to securitize and Speech Act Theory in Copenhagen}

It is surprising that so very little attention has been paid to a theorization of power in CS securitization literature. We argue that the reason for this lies primarily in the aforementioned realist heritage in the original approach. Power is then assumed to be found with pre-existing positions of statist power, which are supposed to constitute institutionalized and conventional contexts within which securitizing speech acts take place. While the application of speech act theory has brought many advantages to the field of security studies - particularly by placing attention on the linguistic construction of knowledge and threat - it has stopped short of analyzing an important missing link between the dynamics explicated by Austin and Searle and the reasons for and mechanisms of 'acceptance' of the securitizing move. The latter is not to be found within the theoretical framework of the speech act theory, but within a theory of discourse. Because of this, the role of the speech act within the overall approach of securitization should be re-evaluated.

We will give a brief overview of our understanding of the speech act theory as background to this criticism. Based on an instrumentalist understanding of the production of meaning in language, the speech act approach originally developed by Austin and further developed by Searle aims to analyse the structure internal to language-based action and its possible effects. While the speech act approach can explain which aspects are likely to be needed for any intended listener to understand the communicative intentions of the author of the speech act, there is no explanation as to the necessary factors for the listener to accept and support the proposed content or claim. That is, the question which factors transfer the performance of the speech act into an act with political consequences is not the focus of the theory. Illocution refers to the type and function of the language-based action which is meant to be undertaken (by the speaker) and understood to be undertaken (by the listener) in the act of speaking. Such functions may be to promise, to claim, to demand, etc. The two meant and understood illocution - may differ from each other. The perlocutionary act refers to the consequences of a language-based action 
which do not include the conventionalized effects - by saying A, I do B. ${ }^{31}$ By claiming something, the listener may be convinced, for example. However, Austin suggests that in some highly institutionalized procedures, conventional consequences should be understood as part of the illocutionary act - by saying A, I do A. ${ }^{32}$ This is the case in the oft-cited examples of naming a ship and marrying a couple (under the correct institutionalized settings, respectively). In the cited cases, it is a conventionalized action, which brings that which it declares into being in and through the act of speaking. It is this understanding which the early CS framework utilized, reducing securitization to "a conventional procedure in which the "felicity circumstances' must fully prevail for the act to go through". ${ }^{33}$

Few such clear conventional consequences, however, exist in the field of security (or politics at large). As Huysmans outlines, two contradictory aspects are contained in the notion of the securitizing speech act, which demonstrates the tension between an illocutionary and perlocutionary understanding thereof. The break with normality embodied in the invocation of a state of exception is, firstly, "connected back to normative and political orders that provide the basis for evaluating and contesting the acceptability of transgressions in terms of calculable consequences of the act". ${ }^{34}$ This includes the calculability of 'speaking security' and refers to institutionalized consequences of the speech act. Securitization in this reading is the orderly transgression of order and, because of this, not beyond order at all. In a contrarian aspect, "“security' is a specific move that entails consequences which involve risking oneself and offering a specific issue as a test case (Wæver, 1995: 75)". ${ }^{35}$ In this respect, we are confronted with the absence of institutionalized, foreseeable consequences of the speech act. This perspective is further underlined by the suggestion that "securitisation can never be only imposed, there is some need to argue one's case", 36 so that "success depends on perlocutionary effects". ${ }^{37}$ An understanding of securitization as an illocutionary act ultimately only works if assuming that fully conventionalized patterns and authorized speaker positions do

31 Austin 1962, pp. 102, 106.

32 Id., pp. 102, 103.

33 Balzacq 2005, p. 172.

34 Huysmans 2011, p. 374.

35 Id., p. 373.

36 Buzan et al. 1998, p. 25.

37 Vuori 2011, pp. 160, 161; see also Guzzini 2011, p. 331. 
exist. It displays a fixation on pre-existing, usually state- and elite-centric, institutionalized positions of power stemming from the realist tradition of thought.

\section{The analytical category of 'success'}

Two additional analytical categories, demonstrating an underlying unease with an understanding of security as an illocutionary act, have been introduced to the theoretical framework - the 'audience' and the application of extraordinary means as a measure of success. Success has, from the earlier writings of the CS, been part of the understanding of securitization. Securitization is supposed to lead somewhere - that is, the justification of the application of extraordinary means. ${ }^{38}$ These extraordinary means then become the de facto proof for 'success.' This perspective faces several challenges. Firstly, securitization does not necessarily lead to the application of extraordinary means. While securitization may be used to justify the application of extraordinary measures, such an application, and the kind of measure applied, does not automatically arise from securitization. The utilisation of extraordinary measures as a sign of success, hence, sits uneasily within a theoretical framework which derives its strength from introducing performativity (understood as illocution) into its framework of the production of security itself, as the perlocutionary act (which includes the wished-for response of another person but cannot and indeed does not try to explain it), is called upon to confirm that the act was illocutionary in the first place - that it really achieved securitization. This, of course, is contradictory in terms.

A second challenge introduced to the theoretical framework through the category of success is the role of practices. While the notion of success along the lines of the application of extraordinary means places the speech act at the beginning of a process and the application of extraordinary means at its end (and as its proof), several authors, particularly those associated with the Paris School (PS), have demonstrated that both individual physical acts which communicate a threat-situation as well as every-day bureaucratic practices do "not merely follow from securitising speech acts but are part of the process through which meanings of security are com-

38 Wæver 1995, p. 55; Buzan et al. 1998, p. 24; McDonald 2008, p. 569. 
municated and through which security itself is constructed". ${ }^{39}$ In this manner, the "little security nothings," as Jef Huysmans terms everyday practices establishing knowledge about security, may indeed be more significant and form the basis for grand gestures of political speech acts. ${ }^{40}$ This 'knowledge' about security also includes imaginations on the potential ways for acting in the face of threat. Further, acts considered "extraordinary" may also be such which lead to, rather than conclude, an initial communication of threat to a larger social group. A theory of discourse which understands discourses to be also material, as we suggest in accordance with Laclau and Mouffe, includes such acts and practices as an integral part of discourse and therefore does not have to draw a line of separation between everyday practices and dramatizing speech acts. While securitization may be understood in the perlocutionary sense, the theory of speech acts does not connect that which it wants to analyze on the level of individual speech acts to constellations of knowledge or its social construction. It is further not devised to analyse mass communication. It is a valuable contribution to the study of securitization but does not offer the analytical tools to explain which conditions govern (un)successful securitization. It is hence - both in its illocutionary as well as perlocutionary aspects - misplaced as the centre-piece of a theory which aims to explain the social construction of security. A further exploration of the possibilities to integrate insights generated by the PS and the CS may be fruitful in analysing the contextual conditions within which (speech) acts occur. We will come back to the related aspects of power in the next section on the speaker-audience relationship, and focus here on the difficult understanding of performativity within a processual rather than self-referential understanding of securitization.

Difficulties surrounding this nexus between performativity and the meaning of success have in effect played fundamental roles in the creation of different schools of securitization. In the Copenhagen School reading, one must ask: how can the act of undertaking extraordinary means sometimes be proof of successful securitization when other acts beforehand were judged as only attempts at securitization? The central difficulty in linking securitization to particular actions or performances is a quasi-positivist claim, leading to theoretical inconsistency and to challenges in em-

39 Id.; Williams 2003; Hansen 2007; Hansen 2000; Weldes 1999.

40 Huysmans 2011, p. 375. 
pirical studies. Success, then, comes to stand in for a vision of "complete" securitization. This vision of complete securitization does not have to hold for an entire 'society' but can be restricted to a particular audience within society. A conception of securitization relying on hegemonic constructions is at an advantage here, as it does not presuppose the totalisation of a hegemonic identity - and in fact, excludes it as a possibility for two reasons mentioned previously. Firstly, hegemonic formations remain unable to become totalizations of the discursive space due to the constitutive nature of antagonism. Secondly, articulations always remain only momentary decisions - contingent and embedded in a wider space of undecidability, since the possibility remains for elements to distribute over opposing camps. If applied to the realm of securitization, this means that a "complete" securitization - one that is universally accepted - can also never occur. This is a crucial insight for securitization approaches, particularly when considering the role of the definition of success and several challenging factors that derive from it. Because of this different angle, the conceptual framework suggested here is able to not only understand securitization despite counter-movements (such as counter- or de-securitizing movements), but precisely enabled through conflict as part of the process. This is especially relevant, of course, for conflict that aids to construct the antagonist line in the first place.

The central questions, then, move away from ones of 'success' to those of where the antagonist line is drawn and, hence, how the hegemonic construction is composed, which discursive elements it incorporates, how closely they are related, and how broad its basis is. Such an analysis can show us which logics and ways of producing knowledge are thinkable and which are not. The view towards the boundaries of the discourse allows us to differentiate disciplinary power related to the constitution of the discourse as basis for intelligibility rather than perceiving only those differences which render any identities within discourses possible. ${ }^{41}$ Our approach maintains, however, that perfect securitization, just as a perfect identity, can never be reached. Hence, the application of extraordinary means is firmly situated as part of the performative process which is both grounded in the preceding discursive context as well as being part of an ongoing process of any hegemonic project. This includes that each act of representation may further homogenize the collective, which forms the

41 See also Bloom/Dallyn 2011; Hansen 2011, pp. 362, 363. 
hegemonic construction, or make visible the cracks therein caused by the variegated moments subsumed within it. Lastly, it may even cause a break of the entire hegemonic framework through attempting to stretch the boundaries of the empty signifier too far. In this manner, 'successful securitization,' defined, for example, through the undertaking of a military intervention, might result in a backlash on the legitimacy supposedly attained through the process of securitization in the longer run. Cutting off the analysis of securitization at this stage, as is inherently supposed by the CS theoretical setting, is hence likely to leave the analyst with an improper understanding.

\section{Audience}

The category of the audience which was absent in earlier outlines of the CS found mention in the 1998 framework. In this, it has been outlined that a "securitizing move becomes securitization only once an audience accepts it as such". ${ }^{42}$ Similar to the category of success, it sits uneasily with the illocutionary understanding of security expressed in the text. ${ }^{43}$ While it holds the potential to transfer the understanding of security onto an intersubjective terrain, the use of the category has been criticized for having been grossly under-theorized to the point that one may deem it inconsequential. ${ }^{44}$ As Lene Hansen argues, the utilization of the category of audience by Wæver has tended more towards a post-structural understanding in which the audience is not pre-existing the act of communication but constituted in it. ${ }^{45}$ However, this too ultimately neither helps to define the speech act as illocutionary (since the opinions and positions of the audience do not follow a fully institutionalized, or conventionalized, script but have to be studied), nor does it help to understand the nature of factors aiding or hindering the process of securitization.

In the CS framework, those factors that may explain the acceptance of the speech act - and thus relations of power - are relegated to a number of rather vague 'facilitating conditions' securing the acceptance of the security perspective by an audience. These facilitating conditions point us to: a)

42 Buzan et al. 1998, p. 25; see also McDonald 2008, p. 564.

43 Balzacq 2005, p. 179.

44 McDonald 2008, pp. 564, 571-2; Balzacq 1998, p. 177; Côté 2016, p. 542.

45 Hansen 2011, pp. 360, 161. 
the form of the speech act; b) the power position of the speaker; and c) contextual factors such as "conditions historically associated with the threat". ${ }^{46}$ These contextual conditions, however, are central to any understanding of power exerted - who or what is able to exert power by imposing an interpretation of events on the polity? And not least: is 'security' understood as a relevant interpretative framework at all? Stemming from such criticism, constructive revisions of the framework have suggested moving to an understanding of securitization as processual, and to increasing the importance allotted to discourse-based understandings thereof. ${ }^{47}$ Such revisions have emphasized the role of the audience as well as contextual factors.

We agree that it is the thorough examination of contextual factors, understood as discourse, that the speech act approach can be embedded into an explanatory model of securitization. It is the discursive context within which such agency occurs, is enabled, and - most importantly - in which it is heard, understood and judged by others if it is to carry meaning for the social construction of security. We contend however, that the very categorization into speaker and audience is not helpful here. Any approach maintaining such a split between audience and speaker must (implicitly) refer back to contextual factors, which affect the audience but not the speaker. The speaker can use contextual circumstances - framed through discursively created understandings and logics - in a strategic manner, while not being affected by these contextual factors him/herself. However, attempts at securitization can only ever occur on a shared basis of intelligibility. As Lene Hansen has pointed out, it is the inter-subjective nature of security, as defined "among the subjects" 48 conceived of in the CS which renders the approach innovative. ${ }^{49}$ Inter-subjectivity, however, refers to different levels of analysis when considering the CS and the hegemonic analysis proposed in this paper. The Copenhagen understanding of security, as taking place among subjects, refers primarily to the process of acceptance of a securitizing move. In post-structural discourse analysis on the other hand, it refers to the more structural level of intelligibility - similar to Foucault's notion of 'episteme.' As Guzzini argues, while "perceptions can be subjectively varied, but are not reducible to personal whim,"

46 Buzan et al. 1998, pp. 31-32.

47 Stritzel 2011, p. 2492.

48 Buzan et al. 1998, p. 31.

49 Hansen 2011, p. 358. 
the question is directed toward that which grounds their condition of possibility. ${ }^{50}$ In our approach of hegemony analysis, inter-subjectivity does not relate to the negotiation of pre-existing subject positions. Rather, articulations are made within a pre-existing discursive field of intelligibility. It is their re-articulation, however, which partially fixes their meaning. The form of such articulation again "may have important consequences [...], and contribute decisively to the shaping of common sense of the masses". ${ }^{51}$ It is hence vital for this study of processes of authorization and power to emancipate itself to a good degree from the very analytical figure of the speaker as well. A more detailed consideration of this analytical figure of the speaker and its relationship to structure and agency is necessary. If such an explicit consideration is not present, the understanding of all impulses introduced into the discourse can be expressed and understood only through this narrow analytic construct of the speaker, while the audience is understood as rather passive and homogenous with relation to power.

The category of 'audience,' on the other hand, implies a rather passive counterpart, largely responding to clues used by the speaker for the attainment of strategic goals. In this manner, Thierry Balzacq suggests "to think of security pronouncements ... as discursive techniques allowing the securitising actor to 'induce or increase the (public) mind to adhere to the thesis presented to its assent' (Perelman and Olbrecht-Tytecka, 1969: 4)". 52 Empirical studies demonstrate, however, that such a straightforward relationship between the securitization attempt and the audience's acceptance should not be presupposed. In this vein, Vuori argues that the intended perlocutionary effects may differ from the explicit justification. Intentional aims may for example also be to express a warning or deterrent, to frame post-hoc justifications for actions or to induce "a controlled silence". 53 Further, the focus on individual moves continues to exclude the possibility of securitization occurring incrementally without any one decisive, intentional move towards it. ${ }^{54}$ Beyond this, it also denies the potential that a speaker's statement is not intended but utilized by an audience (or individuals therein) to securitize a situation. It further denies the potential that an actor expressing views of securitization may not do so for strategic pur-

50 Guzzini 2011, p. 330.

51 Laclau/Mouffe 1985, p. 158.

52 Balzacq 2005, p. 72.

53 Vuori 2011, p. 160.

54 McDonald 2008, p. 569. 
poses but as an expression of genuine (and socially conditioned) conviction that security - understood here as a signifier - is the only logic applicable to the perceived circumstances. Consequently, we firstly need to consider here that members of the 'audience' are actors themselves inasmuch as they relay, modify, multiply or counter statements. Adam Côté, in a meta-analysis of 32 empirical securitization studies, has outlined the rather variegated and mostly very active role of the audience. Thus, he finds that in several case studies, the audience "actively challenged, questioned, and/or supported claims [...] undertook independent actions to modify, bolster, or destabilize security meanings," were able to actively act upon and interpret the contextual circumstances so that their agency cannot be seen as being merely produced by those circumstances. ${ }^{55}$

Beyond this, we argue that there is no context on which a speaker may rely which does not affect him or her as well. Such an understanding would have to be premised on either a) the speaker being completely disjoined from the knowledge-base of the listener, or b) a reality outside of the discursive knowledge-base to exist to which the speaker has access but not the audience. Such an understanding is mirrored in the assumption that "language does not construct reality, at best, it shapes our perception of it," while some occurrences such as 'brute threats' contain an essence which is not constituted through discourse. ${ }^{56}$ While we agree that context is important and its inclusion and theorization is of great value to any theory of securitization, we do not agree with an understanding that some parts of reality are beyond the discursive construction. As Laclau and Mouffe outline, a discourse-theoretical approach does not relate to the ontological question whether a reality outside of discourse exists. It instead insists that any perceived reality can only be made sense of within the relationality of discourse. ${ }^{57}$ Discourse here is the central category which establishes the anchor of shared understandings of differing subject positions, within which the norms, values and preferences are understood and negotiated. It "delineates the terms of intelligibility whereby a particular reality can be known and acted upon". ${ }^{58}$ Arguably, particularly those issues which are constructed as being outside the discursive framework, thus attributed an intrinsic essence, are those which form the most stead-

55 Côté 2016, pp. 550, 551.

56 Balzacq 2005, pp. 181, 190.

57 Laclau/Mouffe 1985, p. 94; Holzscheiter 2014, p. 144.

58 Doty 1996, p. 5. 
fast basis of the relational web of construction of meaning. Following this logic to its end entails that also the fear of (abstract) death - and thus the logic of security - is such a constructed understanding. The concept of insecurity and threat hence presupposes an actor's awareness of circumstances judged to constitute these.

\section{State-centrism}

The CS has largely imagined the speaker-audience relationship to be structured through the entity and influence of the state as the locus of power over defining threats and security. We argue that this is neither entirely accurate nor entirely false. Rather, we contend that structures of the state are part of the more fundamentally institutionalized discursive context within which securitising acts occur.

While the CS has traditionally assumed power to lie with state elites, various studies have demonstrated that these are not necessarily the actors most likely to successfully push for securitization. As a consequence, Holger Stritzel has argued that "positions of power within discourse to 'define security' should not simply be assumed but should rather be an essential element of empirical analysis itself: an assumption of authority should be replaced by the empirical study of processes of authorization". ${ }^{59}$ While he makes an important point here, it remains important not only to re-conceptualise the distribution of power to securitize. Such a perspective views the concept of power too narrowly, since it does not touch upon the power of security as a logic of social relations, and presupposes a basic acceptance of this logic. Here, the study of hegemony again proves helpful and indeed essential. It is able to analyse the web of intelligibility within which an acceptance of the logic of security is based and constructed. A central aspect of this is the understanding of the construction of claims to representing society and polity through, and in response to, constructions of threat and security. States have, from the classical tradition founded by Machiavelli's writings onwards, dominantly been understood as instruments attempting to create security from the sphere of international anarchy, thus enabling the very existence of polities. ${ }^{60}$ While the state struc-

59 Stritzel 2012, p. 556.

60 Huysmans 1998. 
tures of power to securitize as pointed out by CS certainly exist, these are not independent factors but created through the relationship of actors of which they attempt to make sense. Guzzini here adequately outlines that "the realist reading of security ... is not to be understood as the 'essence' of security but rather as the effect of a historical development in which certain actors have come to be authorized to talk and effect war and peace in a 'realist' way". ${ }^{61}$ Developing this argument further, one may call (state) institutions conventionalized or codified positions of power in discourse. The central point here is that "any form of power is constructed in a pragmatic way and internally to the social, through the opposed logics of equivalence and difference; power is never foundational". ${ }^{62}$ In the case of security, this means that in traditional analyses, as in the CS, we can observe a merging of the discursive constructs of security and the state. However, the authority and power with which both are endowed is also internal to discourse. Two points follow from this analysis. Firstly, states or state representatives do not necessarily hold power over dynamics of securitization. Their power depends on the acceptance of the conventionalized positions of power they attempt to embody. Where the state is discredited as a legitimate actor, it does not hold such power - the array of possible positions state representatives can legitimately take are also restricted based on dominant discursive patterns. Secondly, an analysis of alternative claims to the power to securitize hence does not radically question the logic of security but merely challenges the (institutional) structures through which it is channelled. Hegemony analysis holds two advantages here. It can point us toward the question of which potential claims on the creation and constitution of 'society' and polities are excluded. What is more, it shows clearly that both the individual securitizing move and the position of the speaker (as state representative or other) are shaped by, in and through discursive formations. Hegemony analysis can hence help us to apply the called-for analysis of the constitution of power, while on the one hand evading the difficult state-centric heritage of the CS and on the other hand not neglecting potential positions of power and influence channelled through (the discursive figure of) the state.

This understanding also carries a wider implication for the relationship between the CS and PS approaches. The Paris School's focus on (institu-

61 Guzzini 2011, p. 335.

62 Laclau/Mouffe 1985, p. 129. 
tionalized) and bureaucratic practices that may directly or indirectly enable securitization of a given issue can be reinterpreted as an essential component of an analysis of hegemonic discourses. Such practices are enabled through a shared understanding regarding functions which particular state or other actors are tasked to, and allowed to undertake. Once they are undertaken in one fashion or another, they discursively impact the subject issue (as well as on the institutions which authored the act). While some institutions may have the power to act in ways which individuals or other institutions cannot (including the creation of statistics, using military and financial means etc.), ${ }^{63}$ this is not to be equated with the power to securitize. The power to securitize is always a combination of an articulation and the way in which this articulation resonates and is taken up within broader discourse. This perspective, as it locates power in discursive formations, fundamentally calls into question the binary speaker-audience relationship assumed by CS-inspired approaches to securitization. While there appears to be a binary logic in articulation and resonance, we must keep in mind that the articulation itself is affected by the discursive system of intelligibility it attempts to influence. The speaker-audience dichotomy tends to ignore that those aspects seen as constituting the position of the speaker, implicitly or explicitly, are of a structural - that is, discursive nature. An approach based on the presumption of fixed positions of influence further underrates the ability of such structures of meaning-making to change within the process of their attempted fortification. Hegemony theory adds this aspect through reminding us that "hegemonic discourses always only imagine themselves as the appropriate order representing a specific field" 64 and are able to exist only through antagonism.

Hegemony theory can go some way in this respect as it is able to consider in more detail the dynamics and structures that lead to power within discourse. The power to securitize then lies within rules of the social - all of which are, essentially, discursively constituted. It is the structure of discourses that determines which subject-positions may carry legitimacy as well as which institutionalized positions carry weight and meaning under which circumstances. The power to securitize then essentially lies on the level of differences within discourse, while the power of securitization is the constitution of an antagonist divide. Both levels, of course, cannot be

63 See, for example, Hansen 2000.

64 Stäheli 2000, p. 55, authors' translation. 
analyzed independently of each other. Hegemony theory offers a perspective to combine the analysis of these two levels. It allows us to move beyond the speaker-audience dichotomy, and offers a view on the processual formation of identities through the drawing of antagonist lines. Its explanatory power hence extends to both the question of the boundaries of the discursive formation and simultaneously allows to account for change in this formation. The hegemony approach articulates an understanding of politics as the conflictual negotiation of that which represents the common space. ${ }^{65}$ In this understanding, securitization is not the end of normal politics but part of it.

\section{'Financial stability' - The referent object and empty signifier}

In the following it will be shown, by way of example, how securitization approaches may be fruitfully enhanced by a discourse theory of hegemony. 'Financial Stability' will be analysed both as a reference object and as a hegemonic framework. Thereby different (power) dynamics of and within processes of securitization that offer a more throughout analysis of how the language of threat and security shape (political) discourses become apparent.

The Financial Crisis of 2008-09 seems to be a 'classical case' of securitization in the Copenhagen sense. The near collapse of the financial system, most prominently the breakdown of Lehman Brothers, invoked political discussions about how similar events may be prevented in the future. There seems to be a political consensus that financial market practices had been misguided and abused by greedy 'banksters.' Speculation and gambling were deemed to be the causes of the crisis. As a consequence, political leaders expressed the need to react in order to 'calm the markets' and to prevent worse from happening. The security of the population in financial terms and of the financial system as a critical infrastructure were depicted as threatened and in need of protection. ${ }^{66}$ Extraordinary measures were taken to rescue banks and maintain the financial system. Billions of euros and dollars of public money were made available overnight. The causes of the crisis and possible consequences were debated in the broader

65 Nonhoff 2006, p. 109.

66 Langley 2014; Boy/Burgess/Leander 2011, p. 116. 
public and among policy-makers and experts. While within the broader public debate all sorts of crisis interpretations, such as the end of capitalism and the return of the strong state, circulated, ${ }^{67}$ crisis explanations within the circle of high-level political decision-makers were narrowed to a perspective that only focused on ensuring ongoing financial circulations. This discursive narrowing was based on crisis explanations that rest on specific epistemologies. These include financialised methods and techniques of economic handling that were all present within the administration of the crisis. As Paul Langley explains, "crisis management mobilized a diverse array of calculative devices of economy, not least because they provided quantitative, material indicators of the extent and nature of the problems at hand" 68 . This kind of crisis management can only be understood when considering the hegemony of certain kinds of economic thinking, foremost neoclassical convictions, which were in place before the crisis and were reproduced post-crisis. This hegemony is based on a number of circumstances, such as the prevalence of an "economic style of reasoning" among policy-making elites, ${ }^{69}$ as well as the dominance of financial capital in (especially United States) politics, and not least "its central place within the accumulation regime," meaning the increasing influence of finance on everyday life. ${ }^{70}$ In addition, there have been insightful contributions that trace the historically close connections of finance and the state ${ }^{71}$ and show the political nature of the distinction between financial speculation and gambling. ${ }^{72}$

\section{Securitization of finance - The referent object of financial stability}

It is essential to consider the market-based-principles of the hegemony to understanding why high-level politicians such as United States President George W. Bush as well as European leaders provided an interpretation of the crisis in which financial practices and the financial industry itself were conceived as threatening and in need of stricter regulation. At the same

67 Hassel/Lütz 2010, p. 252.

68 Langley 2014, p. 9.

69 Hirschman/Berman 2014, p. 790.

70 Scherrer 2011, p. 227.

71 Boy 2015.

72 De Goede 2005. 
time, financial markets in general and ongoing financial flows were recognised as a common good which needed to be protected. In many of their speeches and interviews, western politicians used the term 'financial stability' (or German 'Finanzmarktstabilität') to describe what needed to be restored, protected, and maintained for the future. This term evolved to be the antagonist to a declared status of crisis. While in the time of immediate crisis management the aim of political action was to overcome crisis, in the years that followed the crisis the signifier 'financial stability' served as a constant reminder of what had to be avoided by any means.

One remarkable example has been provided by former US President George W. Bush in one of his first speeches to explain the crisis and the government's action to the public. At the peak of financial turmoil, on September 24, 2008, Bush gave an 'Address to the Nation on the Financial Crisis,' employing the language of threat and security to legitimize the government's action of bank-bailouts. He first provided a short explanation of the situation as "an extraordinary period for America's economy," which he describes to be "in danger." After giving his analysis of the situation, he explained that he was faced with a choice: "To step in with dramatic government action, or to stand back and allow the irresponsible actions of some to undermine the financial security of all." He legitimized his intervention in the financial markets - normally unthinkable for Republicans as the staunchest believers in enabling market forces - with an apocalyptic outlook on possible consequences if these actions were not taken:

"More banks could fail, including some in your community. The stock market would drop even more, which would reduce the value of your retirement account. The value of your home could plummet. Foreclosures would rise dramatically. And if you own a business or a farm, you would find it harder and more expensive to get credit. More businesses would close their doors, and millions of Americans could lose their jobs. Even if you have good credit history, it would be more difficult for you to get the loans you need to buy a car or send your children to college. And ultimately, our country could experience a long and painful recession." 73

These concrete and personalized scenarios sustained the abstract threat of a financial meltdown and help to legitimize the government's 'rescue plan' that had already been decided upon. At the end of his address, Bush promised to reinforce various regulations "once the crisis is resolved" by

73 Bush 2008a. 
closely examining "operations of companies across the financial spectrum and ensure that their practices do not threaten overall financial stability."

About a month later, on the morning of October 10, 2008, after global financial markets had experienced their worst weeks for decades, the President gave another short statement in the White House Rose Garden:

"Good morning. Over the past few days, we have witnessed a startling drop in the stock market - much of it driven by uncertainty and fear. This has been a deeply unsettling period for the American people. Many of our citizens have serious concerns about their retirement accounts, their investments, and their economic wellbeing. Here's what the American people need to know: that the United States government is acting; we will continue to act to resolve this crisis and restore stability to our markets." 74

Financial stability was the core term that was used to mark what on the one hand had to be restored because it was lacking in the state of crisis, while on the other hand what had to be protected in the future. It was the referent object of securitizing moves that rendered certain practices within the financial markets as threatening. Similar to what the Copenhagen School model has emphasized, the statements helped to legitimize the extraordinary actions of state elites to intervene in financial markets.

Similarly, the German Chancellor invoked 'Finanzmarktstabilität' (financial stability) to legitimize the passing of a bill that should stabilise financial markets ('Finanzmarktstabilisierungsgesetz'). These laws were decided upon exceptionally quickly, considering the fact that billions of euros were at stake. The cited passage gives an example of how Merkel framed the crisis in order to justify these extraordinary policies. First, she declared financial markets an important public good that needs protection. Then she explained how this public good, the financial markets, was threatened. And she renewed the securitizing move by stating that the "threat to financial stability is not tamed yet."

"The financial system plays a central role to ensure the working of the broader economy and thereby to ensure growth and employment. (...) Our proposed law serves to protect this system. Even more so it serves everybody, it serves the public good." (...)

"Let me say it clearly, the threat to financial stability is not tamed yet. We must act as quick as possible and pass the law to lay the foundation for the markets to calm. This is decisive for growth and employment." 75

74 Bush 2008b.

75 Merkel 2008, authors' translation. 
These examples represent a broader political discourse that dominated the immediate political crisis management and thereby provided a discursive frame that foreshadowed post-crisis efforts on financial governance. They show that political leaders used the language of security to describe the events and political reaction to the financial crisis. The period of immediate crisis management, from summer 2007 until the end of 2009, entailed both intense political pressure to prevent the financial trouble from becoming a full-blown economic crisis and a small circle's crisis-management efforts conducted behind closed doors. This opaque form of crisis politics adjusted its political practices to the requirements of the financial market, meaning that political actors strove foremost to prevent any further financial distress. Decisions were taken on the weekend and presented before 'the markets open,' meaning before the stock markets around the globe started their daily business. Within political decision makers' public statements, 'financial stability' was used as the referent object which needed to be restored and protected. It was the discursive antagonist to the 'crisis,' the threatening Other. Similar to what Jef Huysmans outlines for the 'thick signifier,' the empty signifier received meaning through its antagonistic relation to other signifiers (crisis, instability) in a chain of other signifiers, such as a threat to financial stability that put the qualifier in relation. ${ }^{76}$ Huysmans also highlights that signifiers like 'security' are not a neutral device of expression. In relation to the language of security, financial stability implies a certain meaning and a "particular signification of social relations"77. How these social relations unfolded will be analysed in the following section.

Following the crisis, 'financial stability' became an omnipresent term. It was used to refer to the desired condition of the financial market - globally and nationally. An analysis informed by discourse theory of hegemony leads to the question: What conditions led 'financial stability' to become a unifying sign for the post-crisis regulatory discourse? As the construction of hegemonic formations is always relational to the construction of a radical Other, we have to examine what the radically different entailed - that is, to analyse those elements to which financial stability necessarily related in order to become an interpretive framework of financial governance.

76 Huysmans 1998, p. 228.

77 Id. 
The threatening Other, the undesired in the discourse on financial regulation was the emergence of another financial crisis similar to the one that had just occurred. This corresponds to the Copenhagen securitization approach. The threat of another financial crisis served as constant legitimation for the extraordinary measures that were taken as immediate crisis response as well as following political efforts to regulate financial markets. By constantly renewing the threat of a possible financial crisis, political decisions-makers gained legitimacy and defended their interference in financial markets - even if they considered themselves a 'strong believer in free enterprise,' as the former American president did. By analysing the discourse of financial regulation, we can observe how this threatening Other was constructed and mobilized in temporally differing dimensions. The first dimension implies a look backwards to the preceding financial crisis which had just been overcome, and the second dimension refers to future imaginaries and the prevention of a similar crisis which was the central aim of policy-making. 'Financial stability' was considered a public good because it was intended to reduce insecurity for the profoundly financialised societies of many western democracies. Personal savings, stock market exchange, bank loans and the production-based economy relied on a functioning financial system. At the peak of the financial crisis, some of these market activities nearly came to a standstill. Although it remains unclear when and if a condition of 'financial stability' is reached, the perception of absence of crisis already carried effects. The 'diagnosis' of a situation as a crisis or not-crisis situation makes it 'governable'. ${ }^{78}$ These effects show that 'financial stability' does not refer to an external reality, but interprets, and in doing so, constructs reality.

'Financial stability' related to the threat of crisis as its antagonist, which made the constitution of (unusual) blocs possible. For political decisionmakers, financial stability entailed the prevention of another large-scale crisis that would possibly make another government intervention necessary. Several institutions of financial policy-making - the International Monetary Fund (IMF), the Bank for International Settlements (BIS) and central banks - gained legitimacy to enhance their monitoring and assessment of financial market activities. Central bankers supported this because it added another pillar to their responsibilities, and was able to embrace new concepts such as 'systemic risk.' Finally, for market participants it

78 Wansleben 2011. 
promised a comeback to a normalized state of affairs in which they could conduct their business without considering possible financial turmoil. Striving and working for financial stability became hegemonic, meaning it became "widely shared common sense" and common political will. ${ }^{79}$ These characteristics of an empty signifier were an asset on the level of policy-making, but they were an obstacle on the level of implementation.

An analysis following the Copenhagen School approach would probably stop at this point and declare a 'successful' securitization. Political elites performing the securitizing move claimed authority for the use of extraordinary measures and thereby also strengthened the state's priority in dealing with security issues. 'Financial stability' was established as referent object to be protected against future financial crises. However, the case of the financial crisis shows, crucially, why this kind of analysis leaves us with an incomplete picture. The following section will demonstrate why it is important to have a broader framework of analysis, as there is a discrepancy between the ability to securitize and to control the effectiveness of securitization.

\section{Expert discourses and the hegemony of 'financial stability'}

Following the immediate phase of crisis management, after the public securitisation of finance in the Copenhagen sense, legitimizing the use of extraordinary measures, debates on how to prevent another large-scale crisis began. The debate about the future policy framework, however, was less public than the just-cited securitization of the financial system. While financial regulation remained for some time central to 'high politics' 80 and a small circle of experts on financial governance had been in place before the crisis, discussions about 'greedy bankers' did not fill newspaper pages anymore. Hence, starting from late 2008 and most obvious in 2009 and the following years, we find different discourses that were concerned with the consequences of the crisis. During the high times of crisis management, especially in 2008 , we find a vivid public discourse that was dominated by demands for stricter rules for an out-of-control financial industry. At the same time, there was an expert discourse among the members of a rela-

79 Mouffe 1993, p. 53.

80 Engelen et al. 2011, p. 165. 
tively small group within the financial-policy elite who had a direct influence on policy-makers. These two levels of discourse - a crisis-oriented, politicised public discourse and a deliberative technocratic one - developed independently. ${ }^{81}$ The experts who were consulted by policy-makers did not react or refer on the public discussion, and there was little media coverage of how their discussions of financial regulation evolved over time. What unites both discourses and the subject positions involved is the concern about the avoidance of another crisis which is connected to the empty signifier 'financial stability.' In both discourses an antagonist line is drawn between the desired 'financial stability' and the threat of crisis.

After 2009, the public interest in financial regulation decreased and the discursive dramatization lost momentum. This was partly due to the fact that the sovereign debt crisis in Europe - also caused by the financial turmoil of the financial crisis event of 2007-08 - received most of the public's attention in late 2009. Public discourses switched to the threatened failure of currency that was depicted as more pressing than the threat of an unstable financial system. The possible break-up of the Eurozone appeared potentially devastating as it implied severe consequences that endangered the survival of the European Union. ${ }^{82}$ The social upheaval that could result if the currency union failed was considered more dangerous than the abstract threat of financial market distress. The securitization of the Euro Crisis thereby led to a de-securitization of the global financial crisis and the issue of financial regulation; in Lene Hansen's terms, one can speak of 'desecuritization by replacement'. ${ }^{83}$

By framing the causes of the crises less morally and rather technically, the discourse of financial regulation was primarily held within rather small circles of experts and less visible in evening news headlines. These circles had close relations to those political decision-makers who regularly convene in the G20, a forum established in response to the crisis in order to strengthen international financial regulation. In their response to the crisis, the G20 requested the IMF, the BIS and the newly established Financial Stability Board (FSB) ${ }^{84}$ to provide reports on the causes and possible regulatory responses to the crisis. These bodies were a central part of fi-

81 Bieling 2014.

82 Langenohl 2013.

83 Hansen 2012, p. 529.

84 Established by the G20 after the summit in London in April 2009 as the successor of the Financial Stability Forum (FSF). 
nancial market governance before the crisis, and their reports are nodal points within the wider discourse on financial regulation. In their publications, these bodies depicted the causes of the crisis in the insufficient regulation of financial market practises and less in questionable practises themselves. ${ }^{85}$ The reports of IMF, BIS and FSB provided the basis for discussion among political leaders who in turn set the framework for further regulatory work.

The experts of IMF, BIS, and FSB are part of the formations of financial governance that were already in place before the crisis. Central Banks, such as the European Central Bank, the New York Fed and the Bank of England, are also important actors within the discourse on financial governance that is decisive for the apparatus of financial regulation that includes national authorities. Although these apparatuses of security obviously did not prevent the events of the crisis, due to their legitimation through the various bodies they successfully gained legitimacy to be part of the postcrisis regulatory discourse that aimed at establishing new policies. Here we find those "security professionals" 86 and routinized practices of security, such as regulatory controls of banks or the accumulation of data on financial market activities. The aim and promise that the policy proposals initiated in these bodies to serve financial stability helped the financial market experts' position to stake a hegemonic claim. Hence, interventions and regulations that followed the crisis aimed at improving market governance, not at dismantling markets. ${ }^{87}$

In this discourse on how to re-regulate financial markets, 'financial stability,' especially in times of crisis, served as an empty signifier that was able to relate to the dominant subject positions within the financial policy discourse. It related to the position of political decision-makers whose primary aim in the reform process was to avoid another large-scale crisis. They connected with 'financial stability' because, as the discursive antagonist to 'crisis,' it implied for them the future prevention of crises. Several international bodies of financial governance, such as the IMF and the BIS, also related to 'financial stability' because it aligned with their convictions that financial markets monitoring, surveillance and analysis needed to be widened instead of banning particular financial market practices. Their position and legitimacy was strengthened and also resulted in widened

85 Kessler 2013.

86 Bigo 2002, p. 74.

87 Preda 2009, p. 2. 
mandates and expansions of their capacity in terms of staff and financial support.

There are several levels of financial market governance that also connected their action to the empty signifier 'financial stability.' On an institutional level, several high-level bodies and reports were initiated that focused on the issue of financial stability. In the G20's 'Common Principles for Reform of Financial Markets,' (2008) financial stability was the central concern of future international cooperation. Additionally, the G20 established the already-mentioned Financial Stability Board (FSB), whose primary tasks was to monitor and address risks to the global financial system and to develop a new framework for financial regulation (G20, 2009). Additionally, on the supranational level, several high-level bodies were established whose mandates include "safeguarding financial stability," as in the case of the European Systemic Risk Board. ${ }^{88}$ On the German national level, the 'Finanzstabilitätsausschuss' (Financial Stability Committee) was initiated, bringing together German central bankers and politicians concerned with the financial sector to discuss potential threats to financial stability. Also, the IMF reinforced its 'Global Financial Stability Reports.' These measures were also a signal to the public that action was taken to avoid another financial crisis. While changes in financial regulation were less, if at all, visible to the public, the establishment of new financial market authorities was a clear signal. By naming these bodies similar to the empty signifier 'financial stability,' the message was even clearer, and it shows again how the empty signifier connected expert and public discourses. At the same time, economists and analysts working in these bodies substantiated their claim to act and speak as (financial) 'security professionals,' and thereby closure of the expert discourse continued.

\section{Instability of the empty signifier}

After analysing how 'financial stability' connected the public and the expert discourse and how it helped to relate separate subject positions within a hegemonic formation, this section will address how attempts to substantiate the empty signifier led to instability in the discourse formation that had evolved around the empty signifier. This analysis will concentrate on 
the experts' discourse in which economists of several institutions of financial governance are involved. Concerning the question that touched on the concrete interpretations of 'financial stability,' the instability of relations between subject positions and empty signifier becomes apparent. By following the discourse on implementation, the fragility and only temporal fixation is rendered obvious. The more concrete demands to financial stability are, the more contested they become.

The term 'financial stability' is not entirely new to financial governance. It was also used before the crisis, mostly to refer to the interconnectedness of multiple financial intermediaries. However, during this time, regulatory principles rested on the conviction that the purpose of regulation is to ensure the 'soundness' of individual institutions when they lose assets, so-called 'microprudential regulation.' For example, the G7 in 1997 proposed to "develop a strategy for fostering financial stability through the analysis of experiences in previous crises and to elucidate basic standards and principles to guide individual economies in the development of stronger financial systems". ${ }^{89}$ In order to ensure soundness, the pre-2008 crisis approach assesses the risk that individual institutions take, often on the basis of banks' risk models. It assumes the quintessential micro-prudential dictum that "financial stability is ensured as long as each and every institution is sound". 90

Financial stability became open to redefinition, which occurred when it was combined with other concepts in novel ways. ${ }^{91}$ Within the abovementioned influential publications of IMF, BIS and FSB, we do not find a shared and consensual definition of financial stability with regard to constantly changing financial markets. ${ }^{92}$ The following will deliver a closer discourse analysis within the field of financial governance and the bodies that are responsible for monitoring, surveillance and ultimately the consideration of interventions in financial markets. Before new security practices were to be implemented, the broader framework given by political decision-makers needed to be interpreted and turned into concrete practices or, in turn, ongoing security practices needed to be related to shifting hegemonic claims in financial governance.

89 Arner/Buckley 2010, p. 16.

90 Crockett 2000, no pagination.

91 Smith 2003, p. 78, referring to Laclau and Mouffe.

92 Kessler 2009, p. 164. 
As Gabriele Galati and Richhild Moessner describe in their BIS working paper (2011), there was no commonly shared (working) definition of 'financial stability'. ${ }^{93}$ It was often discussed in connection to another buzzword of the crisis: 'systemic risk.' How to define, identify and measure systemic risks was contested as well. However, systemic risks were identified as one of the central causes of the crisis. These risks were not seen as lying with specific financial entities but in between them. New approaches to financial regulation that were introduced following the crisis, most importantly the 'macroprudential' approach to regulation, sought to tackle the threats which systemic risks posed to financial stability. ${ }^{94}$ However, there were considerable differences in what exactly the aim of post-crisis regulation should be. The Bank of England stressed in 2009 that the aim of the macro-approach should be the "stable provision of financial intermediation services", 95 while BIS economists Claudio Borio and Mathias Drehmann argued that it should limit the risk of episodes of financial distress that have macroeconomic costs. ${ }^{96}$ While for the first definition the aim was to enable ongoing financial market flows, the second claim aimed at primarily avoiding costs for the wider economy. When considering concrete policies, these differing aims matter. They caused the post-crisis discourse coalitions to erode as the empty signifier 'financial stability' lost its ability to relate to diverse subject positions within the discourse. It was agreed that regulatory policies should aim at providing financial stability; however, there was no commonly shared definition of 'financial stability'. ${ }^{97}$ It was usually characterized negatively, and circularly, as the absence of threats to itself, i.e. as "being impaired whenever widespread defaults threaten to take place, due to either a banking or a sovereign debt crisis". 98

The lack of a concrete (positive) definition of financial stability can be seen as necessary to gain the support of differing subject positions within the discourse on financial regulation as a whole in order to make a hegemonic claim. As shown, it remained an abstract code that could be connected to differing meanings, and be formulated by differing subject pos-

93 Galati/Moessner 2011.

94 Baker 2013.

95 Galati/Moessner 2011, p. 6.

96 Galati/Moessner 2011, p. 5; Borio/Drehmann 2009.

97 Galati/Moessner 2011.

98 Borio/Toniolo 2011, p. 19. 
itions. By analyzing how the discourse on financial regulations evolves, we can see how these formations become unstable and how the partially fixed meaning erodes. As questions of concrete implementation arose, the concept was quickly criticized because there were no concrete means to measure 'financial stability.' Quantification is essential within a field that rests on the positivistic belief of neutral, evidence-based modelling and objectivity. Subsequently, different market authorities, for example the ECB or the Bank of England, developed their own understandings of how financial stability could be understood in regulatory practice. Also, certain articulations emerged that point to the partly conflicting varieties in the meaning of 'financial stability', ${ }^{99}$ or which questioned the relevance of financial stability as core concept and demanded a shift within the discourse. ${ }^{100}$ The lack of clarity of the empty signifier 'financial stability' becomes apparent and problematized and leads to new antagonisms within the discourse of financial regulation while the unifying effect of a hegemonic formation was lost. Paul Tucker, for example, exposes differing competing interests that all seek to speak in the name of financial stability. ${ }^{101}$

\section{The powerless securitizer? Controlling the effects of securitization}

Analysis of 'financial stability' as a reference object and as an empty signifier permits scrutiny of the claims connected to the hegemonic formation and subject positions from which these were articulated. The Copenhagen School claims that securitization gives legitimacy to political and state elites to leave the realm of 'normal politics.' In their understanding, securitizing speech acts invoke a semantic repertoire by framing a certain problem in the language of security. In consequence, handling this problem is the prerogative of a centralized authority, usually the government of the state. ${ }^{102}$ In the case of the securitization of finance in 2008, we can see the limits of this theoretical framework when considering who had the power to securitize and who had control on the effectiveness of securitizations.

99 Allen 2014.

100 Kessler 2009.

101 Tucker 2016.

102 Buzan et al. 1998; see Langenohl's contribution to this volume. 
Although national political elites decided on the exceptional measures taken in the course of crisis management through (partly) nationalizing banks or bank bailouts, these measures were only taken after careful considerations with other political leaders and non-political elites, such as central bank governors and also leading figures of financial market entities, such as bank chief executives. ${ }^{103}$ Nearly every step that was taken to counter the state of crisis was decided, or at least coordinated, on the supranational level. The following measures to prevent another large-scale crisis were initiated, coordinated and largely prepared for implementation by the mentioned institutions of financial governance. These financial market governance institutions had supported the pre-2007 hegemonic discourse on financial regulation, which was dominated by the conviction that financial markets would self-correct and strict regulation would harm economic growth. However, after the crisis events of 2007-08, this discourse was not able to relate to articulations that arose with the crisis: a strong state and stricter regulation. In order to be included in the post-crisis discourse on financial regulation, actors and institutions that had been able to relate to the pre-crisis hegemonic claim of market efficiency had to demonstrate their ability to relate to the changed discourse. By responding to the crisis with "key lessons from the turmoil" and "policy lessons", 104 they performed a discursive shift toward the rising hegemonic formations that questioned the dogma of financial market efficiency. Already before the crisis, some questioned the hegemony of market efficiency; however, they only succeeded in forming a discursive formation after the events of financial crisis could not be integrated in the discourse of self-correcting and efficient markets. However, the hegemonic formation around 'financial stability' was able to discursively integrate crisis descriptions and claims. In turn, political leaders within the G20 followed these discourse formations in their crisis diagnosis and took up many of their proposed policy responses.

Already during the high times of crisis management and even more so during the process of reform, demands articulated by actors connected to financial markets increasingly gained importance. Their articulations were readily connected to the signifier 'financial stability,' and eventually their interpretations of the reference object were implemented. The discourse

103 Steinbruck 2011, pp. $200 \mathrm{ff}$.

104 IMF 2008, p. 1. 
on the implementation of financial stability connects the speech act of securitization to the level of security practices. On the latter level of providing security, certain actors were empowered to 'create' security. In the case of financial governance, these were certain bodies and financial market authorities whose mandates are widened in order to provide financial stability, such as the ECB and the Bank of England. Within these authorities, we find the 'security professionals' of financial governance that supervise financial market activities. In taking this position they were able to make claims about the rightfulness of financial market practices. It is within these bodies and institutions that the political framework on the provision of financial stability was transferred into concrete methods and policies.

Coming back to the initial observations that political decision-makers made securitizing moves and thereby legitimized their interference in financial markets, the outcome of this process is remarkable, when considered from the Copenhagen School's perspective. Their approach proposes the speech-act theoretical model of securitization, according to which political actors gain legitimacy to act in labelling an economic problem as existential for the existence of the polity. ${ }^{105}$ As cited above, political leaders made such securitizing moves and thereby claimed their right to intervene in and regulate financial markets. It is important to note that in the case of the financial crisis, these interventions were not a straightforward crackdown by political elites. Instead, actors that were decisive in determining which policies were to be taken were part of an elite of financial governance that had already been in place before the crisis. The discourse analysis of hegemony provides a more nuanced picture of how political and financial elites interacted. This continuance emphasises the need to take into consideration the constellations of security practices and tools as well as 'security experts' that are already in place.

The analysis underlines the importance of the different forms of power discussed in Andreas Langenohl's contribution to this volume. Only focusing on the linguistics of the securitizing move does not provide a full picture of power relations and their dynamics. As stated by Langenohl, the power of securitization, meaning "consequences that arise from such acts of securitizing communication," 106 are also part of the securitization pro-

106 Langenohl, in this volume, p. 56. 
cess. An analysis restricted to the Copenhagen understanding of securitization would not consider how the effects of the securitization evolved, although this strongly alters the assessment of the post-crisis developments. Also, focussing on the speech-act of securitization does not consider which hegemonies have already been in place and may have been undermined by the events of the crisis. Focussing on the speaker and the securitizing speech-act may even narrow the analysis by foregrounding actors and speech acts as those that would be decisive without considering where their articulations stem from. In the case of post-crisis financial regulation, the Copenhagen School's framework would leave the researcher with the impression that political elites succeeded in re-claiming their right to govern financial markets. A discourse analysis of hegemony discloses that political decision-makers were not in control of the securitization dynamics in which they were involved. The broader discourse analysis helps to understand how certain actors belonging to the field of financial governance profit from the securitizing move at the expense of the securitizing actors. In the above-cited, securitizing moves political leaders claim to use their agency to act and control financial markets. The analysis of the reform process that followed this securitization showed that while the dramatization of the discourse put pressure to act on the political elites, the empty signifier 'financial stability' allowed only certain articulations to be included into the hegemonic formation. It integrated political demands as well as articulations stemming from an elite of financial market governance. Eventually, it was especially this elite whose particular articulations were linked the empty signifier 'financial stability' and which gained authority in the discourse on financial reform. This relation strengthened their status as experts of financial governance and gave them a prerogative to propose specific security measures and thereby to occupy the position to control the power of securitization.

\section{References}

Allen, Hilary J. (2014): What is "Financial Stability"? The need for some common language in international financial regulation. Georgetown Journal of International Law 45(4): 929-952.

Arner, Douglas W./Buckley, Ross P. (2010): Redesigning the architecture of the global financial system. Melbourne Journal of International Law 11(2).

Austin, J.L. (1962) How to Do Things with Words. The William James Lectures delivered at Harvard University in 1955. Oxford: Oxford University Press. 
Baker, Andrew (2013): The new political economy of the macroprudential ideational shift. New Political Economy 18(1): 112-139.

Bieling, Hans-Jürgen (2014): Europäische Finanzmarktpolitik in der Krise. In: Zeitschrift für Vergleichende Politikwissenschaft 8(1): 91-113.

Bigo, Didier (2002): Security and immigration: Toward a critique of the governmentality of unease. In: Alternatives: Global, Local, Political 27(1): 63-92.

Bloom, P. / Dallyn, S. (2011): The paradox of order: reimagining ideological domination. In: Journal of Political Ideologies 16(1): 53-78.

Booth, Ken (2005): Critical Security Studies and World Politics. Boulder, CO: Lynne Riener.

Borio, Claudio/Drehmann, Mathias (2009): Assessing the Risk of Banking Crises - Revisited. (= BIS Quarterly Review, March 2009.) Basel: Bank for International Settlements. http://www.bis.org/publ/qtrpdf/r_qt0903e.pdf (accesssed May 23, 2016).

Borio, Claudio/Toniolo, Gianni (2011): One hundred and thirty years of central bank cooperation: A BIS perspective. In: Claudio Borio/Gianni Toniolo/Piet Clement (eds.): The Past and Future of Central Bank Cooperation. Cambridge: Cambridge University Press, pp. 16-75.

Boy, Nina/Burgess, J. Peter/Leander, Anna (2011): The global governance of security and finance: Introduction to the special issue. Security Dialogue 42(2): 115-122.

Boy, Nina (2015): Sovereign safety. Security Dialogue 46(6): 530-547.

Bush, George W. (2008a): Address to the Nation on the Financial Crisis. The White House. Washington D.C., September 24, 2008.

Bush, George W. (2008b): Text of President's statement. Rose Garden of the White House. New York Times, October 10, 2008.

Buzan, Barry/Wæver, Ole/Wilde, Jaap de (1998): Security. A New Framework for Analysis. Boulder, Colo.: Lynne Rienner Pub.

Côté, A. (2016): Agents without agency: Assessing the role of the audience in securitization theory. Security Dialogue 47(6): 541-558.

Crockett, Andrew (2000): Marrying the micro- and macro-prudential dimensions of financial stability. Speech before the Eleventh International Conference of Banking Supervisors, 21.09.2000. Basel, Switzerland.

Dalby, Simon (2002): Environmental Security. Minneapolis, MN: University of Minnesota Press.

Engelen, Ewald et al. (2011): After the Great Complacence. Financial Crisis and the Politics of Reform. Oxford/New York: Oxford University Press.

EU-Regulation No 1092/2010 of the European Parliament and of the Council, on European Union macro-prudential oversight of the financial system and establishing a European Systemic Risk Board.

G20 (2009): The Global Plan for Recovery and Reform, London, 2 April 2009, https:// www.g20.org/Content/DE/StatischeSeiten/Breg/G7G20/Anlagen/G20-erklaerung-1 ondon-en.pdf?_blob=publicationFile\&v=1 (accessed June 26, 2017).

Galati, Gabriele/Moessner, Richhild (2011): Macroprudential Policy: A Literature Review. (= BIS Working Papers, No 337.) Basel: Bank for International Settlements. 
Goede, Marieke de (2005): Virtue, Fortune and Faith: A Genealogy of Finance. Minneapolis, Minn: University of Minnesota Press.

Guzzini, Stefano (2011): Securitization as a causal mechanism. Security Dialogue 42(4-5): 329-341.

Hansen, Lene (2000): The Little Mermaid's silent security dilemma and the absence of gender in Copenhagen. Millennium 29(2): 289-386

Hansen, Lene (2011): The politics of securitization and the Muhammad cartoon crisis. A post-structuralist perspective. Security Dialogue 42(4-5): 357-369.

Hansen, Lene (2012): Reconstructing desecuritization: the normative-political in the Copenhagen School and directions for how to apply it. Review of International Studies 38(3): 525-546.

Herschinger, Eva (2012): 'Hell is the Other'. Conceptualising hegemony and identity through discourse theory. In: Millennium: Journal of International Studies 41(1): 65-90.

Hirschman, Daniel/Berman, Elizabeth Popp (2014): Do economists make policies? On the political effects of economics. Socio-Economic Review 12(4): 779-811.

Howarth, David (2010): Power, discourse, and policy. Articulating a hegemony approach to critical policy studies. Critical Policy Studies 3(3-4): 309-335.

Howarth, David R.; Torfing, Jacob (2005): Discourse Theory in European Politics: Identity, Policy, and Governance. Basingstoke/New York: Palgrave Macmillan.

Huysmans, Jef (1998): Security! What do you mean? From concept to thick signifier. European Journal of International Relations 4(2): 226-255.

Huysmans, Jef (2011): What's in an act? On security speech acts and little security nothings. Security Dialogue 42(4-5): 371-383.

IMF (2008): The Recent Financial Turmoil-Initial Assessment, Policy Lessons, and Implications for Fund Surveillance. International Monetary Fund. https:/www.imf. org/external/np/pp/eng/2008/040908.pdf (accesed Febraury 14, 2017).

Keller, Reiner (2011): Wissenssoziologische Diskursanalyse. Grundlegung eines Forschungsprogramms. Wiesbaden: VS Verlag für Sozialwissenschaften.

Kessler, Oliver (2009): Die Subprime-Krise und die Frage nach der Finanzmarktstabilität. In: Zeitschrift für Internationale Beziehungen 16(1): 161-175.

Kessler, Oliver (2013): Die Krise als System? Die diskursive Konstruktion von „Risiko“ und „Unsicherheit“. In: Jens Maeße (ed.): Ökonomie, Diskurs, Regierung. Wiesbaden: Springer VS, pp. 57-76.

Laclau, Ernesto/Mouffe, Chantal (1985): Hegemony and Socialist Strategy. Towards a Radical Democratic Politics. London/New York: Verso.

Langenohl, Andreas (2013): Finanzialisierung politischer Sicherheit. Das Beispiel der ,Euro-Rettung،. In: Ansgar Baums / Christopher Daase (eds.): Verunsicherte Gesellschaft - überforderter Staat. Zum Wandel der Sicherheitskultur. Frankfurt am Main: Campus, pp. 279-297.

Langley, Paul (2014): Liquidity Lost: The Governance of the Global Financial Crisis. Oxford: Oxford University Press. 
McSweeney, Bill (1996): Identity and security: Buzan and the Copenhagen school. In: Review of International Studies 22(1): 81-93.

McSweeney, Bill (1998): Durkheim and the Copenhagen school: A response to Buzan and Weaver. Review of International Studies 24(1): 137-140.

Merkel, Angela (2008): Regierungserklärung von Bundeskanzlerin Dr. Angela Merkel zum Finanzmarktstabilisierungsgesetz vor dem Deutschen Bundestag am 15. Oktober 2008 in Berlin: Bundesregierung. Berlin, 15.10.2008. http:/www.bundesregieru ng.de/Content/DE/Bulletin/2008/10/109-1-bk-bt.html (accessed April 21, 2015).

Mouffe, Chantal (2008): The Return of the Political. London /New York: Verso.

Nonhoff, Martin (2006): Politischer Diskurs und Hegemonie. Das Projekt Soziale Marktwirtschaft. Bielefeld: Transcript.

Norval, Aletta (2004): Hegemony after deconstruction: The consequences of undecidability. Journal of Political Ideologies 9(2): 139-157.

Preda, Alex (2009): Framing Finance: The Boundaries of Markets and Modern Capitalism. Chicago/London: University of Chicago Press.

Scherrer, Christoph (2011): Reproducing hegemony. US finance capital and the 2008 crisis. Critical Policy Studies 5(3): 219-246.

Smith, Anna Marie (2003): Laclau and Mouffe: The Radical Democratic Imaginary. London, New York: Routledge.

Stäheli, Urs (2016): Die politische Theorie der Hegemonie: Ernesto Laclau und Chantal Mouffe. In: André Brodocz, Gary S. Schaal (eds.): Politische Theorien der Gegenwart. Opladen/Farmington Hills, Mich.: Budrich, pp. 253-284.

Steinbrück, Peer (2011): Unterm Strich. München: Dt. Taschenbuch-Verl.

Stritzel, Holger (2007): Towards a theory of securitization: Copenhagen and beyond. European Journal of International Relations 13(3): 357-383.

Stritzel, Holger (2011): Security as translation: Threats, discourse and the politics of localisation. Review of International Studies 37(5): 343-355.

Stritzel, Holger (2012): Securitisation, power, intertextuality: Discourse theory and the translation of organised crime. Security Dialogue 43(6): 549-567.

Stritzel, Holger (2014): Security in Translation: Securitization Theory and the Localization of Threat. Basingstoke/New York: Palgrave Macmillan.

Thomassen, Lasse (2005): Antagonism, hegemony and ideology after heterogeneity. Journal of Political Ideologies 10(3): 289-309.

Thomassen, Lasse (2016): Hegemony, populism and democracy: Laclau and Mouffe today (review article). Revista Espanola de Cienca Politica 40: 161-176.

Tucker, Paul (2016): The design and governance of financial stability regimes. A common-resource problem that challenges technical know-how, democratic accountability and international coordination (= Essays on International Finance, 3.) Waterloo: Centre for International Governance Innovation, https://www.cigionline.org/sit es/default/files/financial_essay_vol.3_web.pdf,14.02.2017.

Vuori, Juha (2011): How to Do Security with Words: A Grammar of Securitisation in the People's Republic of China. (= Annales Universitatis Turkuensis, Sarja - Ser. B OSA - tomus 336 - Humaniora.) Turku: University of Turku. 
Wansleben, Leon (2011): Wie wird bewertbar, ob ein Staat zu viele Schulden hat? Finanzexperten und ihr Bewertungswissen in der griechischen Schuldenkrise. Berliner Journal für Soziologie 21(4): 495-519.

Wæver, Ole (1995): Securitization and desecuritization. In: Ronnie D. Lipschutz (ed.): On Security. New York: Columbia University Press (New directions in world politics), pp. 46-86.

Williams, Michael C. (2003): Words, images, enemies: Securitisation and international politics. International Security Quarterly 47(4): 511-32. 